\title{
Deciduous Dental Morphological Diversity in Contemporary Colombian Ethnic Groups
}

\author{
Miguel Eduardo Delgado-Burbano* \\ División Antropología, Facultad de Ciencias Naturales y Museo, Universidad Nacional de La Plata, La Plata 1900, \\ Buenos Aires, Argentina
}

ABSTRACT: Biocultural diversity of contemporary South American populations has not been studied extensively, therefore delineating some of the patterns of phenotypic variation may be useful for understanding their ongoing evolution. Thirty-seven deciduous dental nonmetric traits were scored on 200 dental casts that were obtained from four contemporary Colombian ethnic groups with different ancestry. Inter-group affinities were assessed by means of a principal component analysis based on trait frequencies. African-American Colombian groups share several dental morphological affinities with other New World African derived populations as well as with Sub-Saharan African dental samples.

Discontinuous variation in the permanent dentition of modern Homo sapiens has been systematically studied from a worldwide level (Scott and Turner, 1997). In contrast, relatively little is known about modern human evolution as depicted in the primary dentition.

Several characters in the deciduous dentition are evolutionarily conservative and have deep phylogenetic and ontogenetic stability in comparison to some traits in the permanent dentition (Edgar and Lease, 2007). Moreover, the early development of deciduous dentition in utero allows less external perturbations (Smith, 1978; Smith et al., 1987). However, some aspects of the deciduous dentition's evolutionary dynamics are not well known, and its use for the study of human evolution is scarce (Kitagawa, 2000; Sciulli, 1998; Smith, 1978; Grine, 1984; Lukacs and Walimbe, 1984; Lease, 2003; Lease and Sciulli, 2005; Delgado-Burbano, 2007).

Although phenotypic characters shown indirectly genetic relationships and environmental factors may affect the underlying genotype, dental nonmetric traits are reliable skeletal characters since they are strongly controlled by polygenic systems and present high heritability values (e.g., Townsend and Martín, 1992; Nichol, 1989).

Several investigations provide information about deciduous nonmetric variation from a local scale in several human groups from Asia and the Pacific (Hanihara, 1956ab, 1961, 1963, 1965, 1966; Hanihara and Minamidate, 1965; Sasaki and Kanasawa, 1998; Kitagawa, 2000), Africa (Grine, 1984, 1986, 1990; Lease, 2003), India (Lukacs and Walimbe, 1984; Lukacs and
Colombian Amerindians have a relative affinity with prehistoric Native North American samples, but a clear association with living North American Indians and recent Northeast Asian Sinodont populations was not evident. The biologically admixed group or "Mestizo" has a more complicated pattern of phenotypic relationships, with an African and an Amerindian but not an evident European component. From an evolutionary point of view, gene flow probably is the most important factor that changed the original gene pool through time. These groups have a complex landscape of biocultural variation reflected by their different microevolutionary histories. Dental Anthropology 2008;21(2):33-45.

Hemphill, 1991), Europe (Lease, 2003; JØrgensen, 1956), Near East (Smith, 1978; Smith et al., 1987; Moskona et al., 1998), Australia (Townsend and Brown, 1981; Townsend et al., 1986, 1990) and North America (Sciulli, 1977, 1990, 1998, Tocheri, 2002; Ullinger, 2003; Lease, 2003; Lease and Sciulli, 2005; Edgar and Lease, 2007). Surprisingly, past and present South American populations have received little attention (Delgado-Burbano, 2007).

Although the current use of molecular variants (i.e., mtDNA, Y chromosome and autosomal markers) in the study of population history and biological variability of modern human populations is very popular, studies based on phenotypic variation continue to play an important role. The study of phenotypic diversity can help us understand the evolution and biocultural variation of the contemporary communities that today inhabit South America and to obtain a more complete landscape of the dynamics that configure their gene pool. The aims of the present research are to (1) characterize some Colombian communities through their deciduous dental variation, (2) assess this diversity in a regional context, and (3) suggest interpretations of their population history, affinities and microevolution.

*Correspondence to: Miguel Eduardo Delgado-Burbano, División de Antropología. Facultad de Ciencias Naturales y Museo. Universidad Nacional de La Plata. Paseo del Bosque s/n. La Plata 1900, Buenos Aires, Argentina.

E-mail: medelgado@fcnym.unlp.edu.ar 


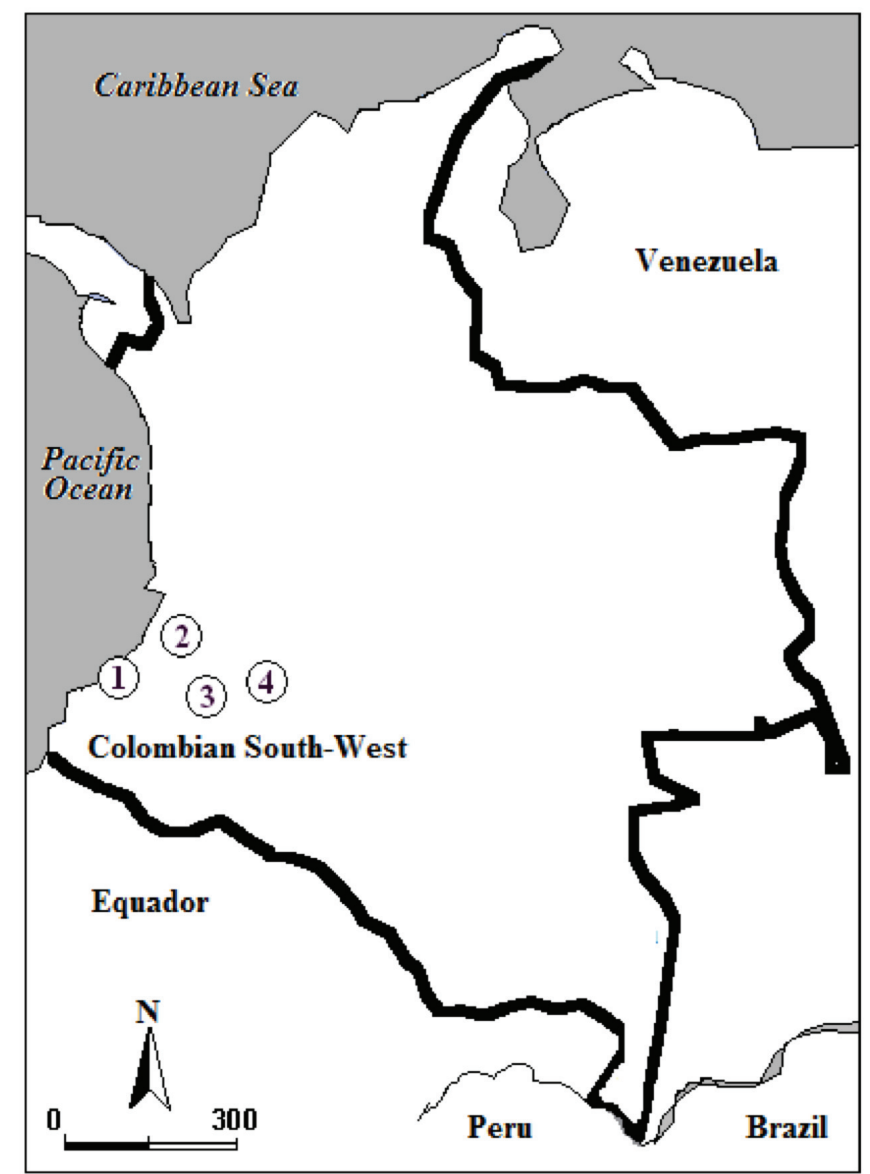

Fig. 1. Map of Colombia showing the geographic location of the populations studied: 1 Guapi, 2 Villarica, 3 Popayán, and 4 Silvia. The scale is in kilometers.

\section{MATERIALS AND METHODS}

\section{Study Subjects}

Dental casts $(n=200)$ were collected and analyzed from four communities with different ethnic ancestry located in the southwest of Colombia (Fig. 1). Sex distribution and sample size for the groups are presented in Table 1. Sixty-eight dental models are from Afro-Colombian individuals of the Guapi community in the Colombian Pacific Coast (Pacific Basin). This group inhabits a rural settlement and their subsistence system is based on agriculture, trade and fishing.
Nineteen dental casts were obtained from Villarica (Cauca municipality [inland]). This community is a New World African descendent population. Their subsistence system is based on agriculture and sugar cane farming. Their history is related to the distribution of African slaves in farms and sugar mills around the Cauca Valley region. These communities are isolated towns whose inhabitants are of African ancestry (> 90\%) with low levels of admixture. Another 56 dental casts were obtained from the Amerindian group Guambiano that inhabits the settlement of Silvia in the Department of Cauca, Colombia. Silvia is a rural settlement characteristic of the highland Amerindian populations of the South American Andes. Guambiano language belongs to Coconucan-Barbacoan family, which belongs to the Chibchan-Paezan or Macro-Chibchan family characteristic of highlands of Colombian southwest and Ecuador (Ethnolgue, 2001). Their subsistence system is based on agricultural activities. Interestingly, according to their mating customs, we expect low rates of European and/or African admixture (Pachón, 1996). The last 57 dental casts were obtained from individuals from Popayán city. This group is known as "Mestizo" (i.e., genetically admixed). Latin American urban populations like Popayán are usually trihybrid (Sans, 2000), with a gene pool composed of varying frequencies of European and Native-American genes, although some African admixture is also expected.

The age and sex of each individual was recorded at the time of casting. The greatest portion of subjects examined in this study are children between 3 and 11 years of age. Only teeth unaffected by wear, pathology, or casting error were included in the analyses. The individual count method was used to record the incidence of trait absence contrasted with all degrees of trait expression (Scott, 1980).

\section{Nonmetric Traits}

Thirty-seven deciduous crown nonmetric traits (19 maxillary and 18 mandibular) were scored following suggestions from several authors (Hanihara, 1961, 1963; Sciulli, 1998; Grine, 1986; Turner et al., 1991; Sasaki and Kanazawa, 1998). For among-group comparisons, dental data from 16 ancient and contemporary groups with various ethnic ancestries were gathered from the

TABLE 1. Sex distribution and sample size of the contemporary Colombian ethnic groups analyzed*

\begin{tabular}{|c|c|c|c|c|c|c|c|c|c|c|c|}
\hline \multicolumn{3}{|c|}{$\begin{array}{c}\text { African Americans } \\
\text { (Guapi) }\end{array}$} & \multicolumn{3}{|c|}{$\begin{array}{c}\text { African Americans } \\
\text { (Villarica) }\end{array}$} & \multicolumn{3}{|c|}{$\begin{array}{c}\text { Guambiano } \\
\text { Amerindians } \\
\text { (Silvia) }\end{array}$} & \multicolumn{3}{|c|}{$\begin{array}{c}\text { Admixed/Mestizo } \\
\text { (Popayán) }\end{array}$} \\
\hline M & F & $\mathrm{T}$ & $\mathrm{M}$ & $\mathrm{F}$ & $\mathrm{T}$ & $\mathrm{M}$ & $\mathrm{F}$ & $\mathrm{T}$ & $\mathrm{M}$ & F & $\mathrm{T}$ \\
\hline 32 & 36 & 68 & 10 & 9 & 19 & 30 & 26 & 56 & 29 & 28 & 57 \\
\hline $47.1 \%$ & $52.9 \%$ & $100 \%$ & $52.6 \%$ & $47.4 \%$ & $100 \%$ & $53.6 \%$ & $46.4 \%$ & $100 \%$ & $50.8 \%$ & $49.2 \%$ & $100 \%$ \\
\hline
\end{tabular}

${ }^{*}$ Codes are Males $(\mathrm{M})$, Females, and Total $(\mathrm{T})$ 
TABLE 2. Dental samples used for population comparisons

\begin{tabular}{|c|c|c|c|c|c|c|c|}
\hline & Code & $\begin{array}{l}\text { Sample } \\
\text { Name }\end{array}$ & $\begin{array}{l}\text { Area } \\
\text { Area }\end{array}$ & $\begin{array}{l}\text { Cultural } \\
\text { Affiliation }\end{array}$ & Period & $\begin{array}{l}\text { Sample } \\
\text { Size }\end{array}$ & Citation \\
\hline 1 & Japan & Japanese & Japan & Asiatic & Contemporary & 183 & $\begin{array}{l}\text { Hanihara, 1963, } \\
1968,1965\end{array}$ \\
\hline 2 & $\operatorname{arc}$ & $\begin{array}{l}\text { Prehistoric } \\
\text { Amerindian }\end{array}$ & $\begin{array}{l}\text { Ohio } \\
\text { Valley }\end{array}$ & $\begin{array}{l}\text { Late } \\
\text { Archaic }\end{array}$ & $3200-2700 \mathrm{BP}$ & 64 & Sciulli, 1990, 1998 \\
\hline 3 & wood & $\begin{array}{l}\text { Prehistoric } \\
\text { Amerindian }\end{array}$ & $\begin{array}{l}\text { Ohio } \\
\text { Valley }\end{array}$ & $\begin{array}{l}\text { Woodland } \\
\text { E-M-L }\end{array}$ & 2700-1000 BР & 34 & Sciulli, 1990, 1998 \\
\hline 4 & pear & $\begin{array}{l}\text { Prehistoric } \\
\text { Amerindian }\end{array}$ & $\begin{array}{l}\text { Ohio } \\
\text { Valley }\end{array}$ & $\begin{array}{l}\text { Late Prehistoric } \\
\text { Pearson/Anderson }\end{array}$ & $1000-350 \mathrm{BP}$ & 61 & Sciulli, 1990, 1998 \\
\hline 5 & sunw & $\begin{array}{l}\text { Prehistoric } \\
\text { Amerindian }\end{array}$ & $\begin{array}{l}\text { Ohio } \\
\text { Valley }\end{array}$ & $\begin{array}{l}\text { Late Prehistoric } \\
\text { Sun Watch }\end{array}$ & $1000-350 \mathrm{BP}$ & 76 & Sciulli, 1990, 1998 \\
\hline 6 & mono & $\begin{array}{l}\text { Prehistoric } \\
\text { Amerindian }\end{array}$ & $\begin{array}{l}\text { Ohio } \\
\text { Valley }\end{array}$ & Monongahela & $1000-350 \mathrm{BP}$ & 62 & Sciulli 1990, 1998 \\
\hline 7 & buff & $\begin{array}{l}\text { Prehistoric } \\
\text { Amerindian }\end{array}$ & $\begin{array}{l}\text { Ohio } \\
\text { Valley }\end{array}$ & $\begin{array}{c}\text { Late } \\
\text { Prehistoric } \\
\text { Buffalo }\end{array}$ & $1000-350 \mathrm{BP}$ & 73 & Sciulli, 1990, 1998 \\
\hline 8 & pima & $\begin{array}{l}\text { Contemporary } \\
\text { Amerindian }\end{array}$ & Arizona & $\begin{array}{l}\text { Pima } \\
\text { So. Arizona }\end{array}$ & Contemporary & 100 & Tocheri, 2002 \\
\hline 9 & safr & $\begin{array}{l}\text { South } \\
\text { Africans }\end{array}$ & $\begin{array}{l}\text { South } \\
\text { Africa }\end{array}$ & $\begin{array}{l}\text { Natal Nguni } \\
\text { Cape Nguni }\end{array}$ & $\begin{array}{l}\text { Contemporary } \\
\text { Prehistoric }\end{array}$ & 53 & Grine, 1986 \\
\hline 10 & wafr & West African & - & - & Contemporary & 18 & Lease 2003 \\
\hline 11 & afm.wash & $\begin{array}{l}\text { African } \\
\text { American }\end{array}$ & $\begin{array}{l}\text { Washington } \\
\text { USA }\end{array}$ & African & $\begin{array}{l}\text { Contemporary } \\
\text { American }\end{array}$ & 249 & $\begin{array}{l}\text { Hanihara, 1963, } \\
1965\end{array}$ \\
\hline 12 & afm.mem & $\begin{array}{c}\text { African } \\
\text { American }\end{array}$ & $\begin{array}{l}\text { Memphis } \\
\text { Tennessee }\end{array}$ & $\begin{array}{l}\text { African } \\
\text { American }\end{array}$ & Contemporary & 117 & Lease, 2003 \\
\hline 13 & afm.dall & $\begin{array}{l}\text { African } \\
\text { American }\end{array}$ & $\begin{array}{l}\text { Dallas, } \\
\text { Texas }\end{array}$ & $\begin{array}{l}\text { African } \\
\text { American }\end{array}$ & Contemporary & 101 & Lease, 2003 \\
\hline 14 & England & English & London & European & Contemporary & 86 & Lease, 2003 \\
\hline 15 & eua.usa & $\begin{array}{l}\text { No. American } \\
\text { White }\end{array}$ & $\begin{array}{l}\text { Cleveland, } \\
\text { Ohio }\end{array}$ & European & $\begin{array}{l}\text { Cnotemporary } \\
\text { Americans }\end{array}$ & 100 & Lease, 2003 \\
\hline 16 & India & Prehistoric India & $\begin{array}{l}\text { West } \\
\text { India }\end{array}$ & Inamgaon & $\begin{array}{c}\text { Calcolithic } \\
\text { 1600-700 BC }\end{array}$ & 45 & $\begin{array}{l}\text { Lukacs, Walimbe, } \\
1984\end{array}$ \\
\hline
\end{tabular}

literature, and these are listed in Table 2. Information regarding analyzed dental traits, break points, and frequencies in Colombian groups are presented in Tables 3 and 4 . Of the total traits analyzed, 18 were used for group comparisons in the multivariate analysis (Table $5)$.

\section{Statistical Analyses}

The first step in the statistical analysis was testing dental trait frequency differences between males and females. This procedure was done by means of the Pearson chi-square test to detect significance $(\mathrm{P}<$ $0.05)$. The next step was to obtain phenetic relatedness between samples using a multivariate analysis of principal components (PCA) using SPSS 14.0 software. Despite the numerous methods available for population comparisons using dichotomous data such as B-squared distance, correspondence analysis, pseudo-Mahalanobis' $\mathrm{D}^{2}$, Euclidean distance, average taxonomic distances, among others, anthropologists have focused almost 


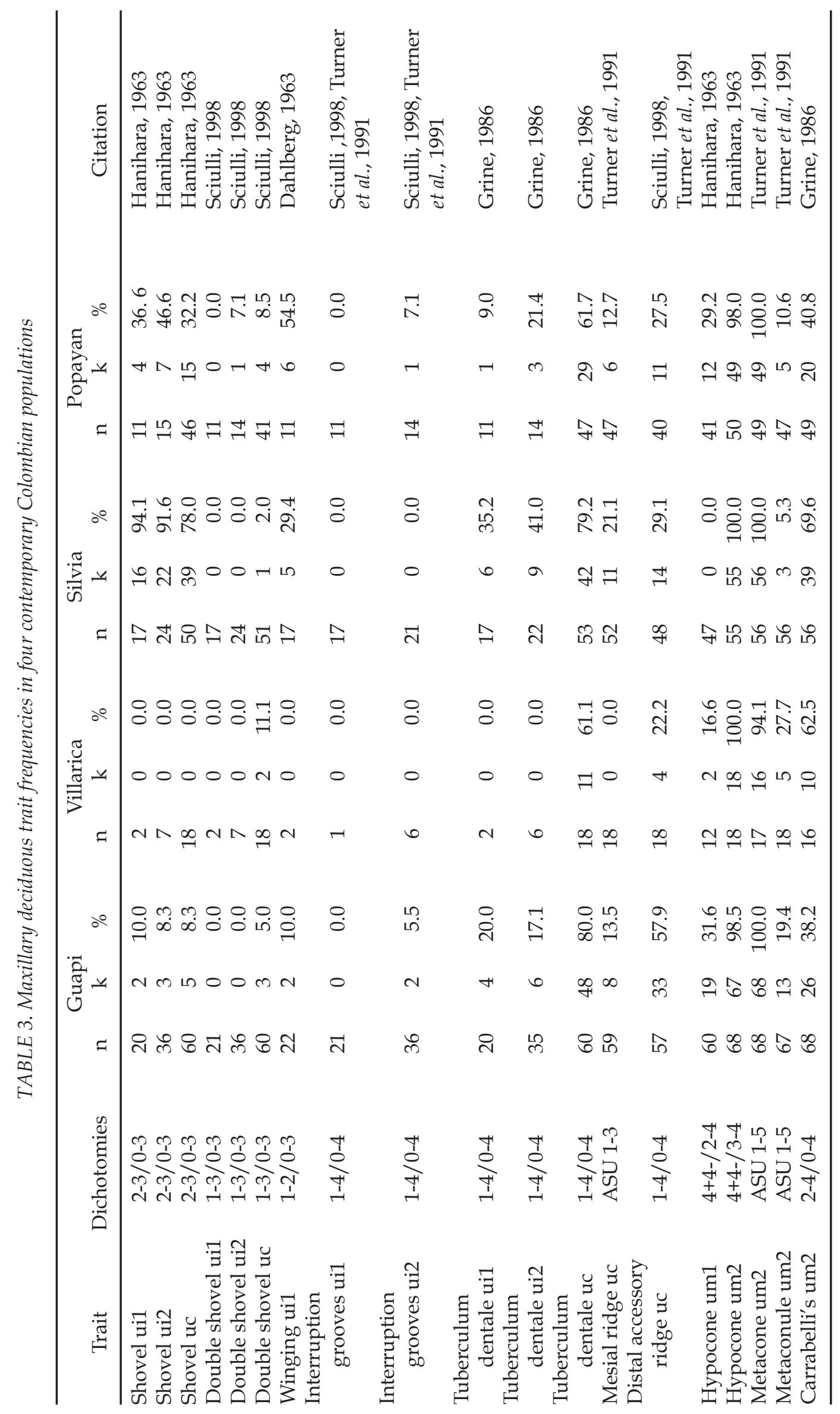




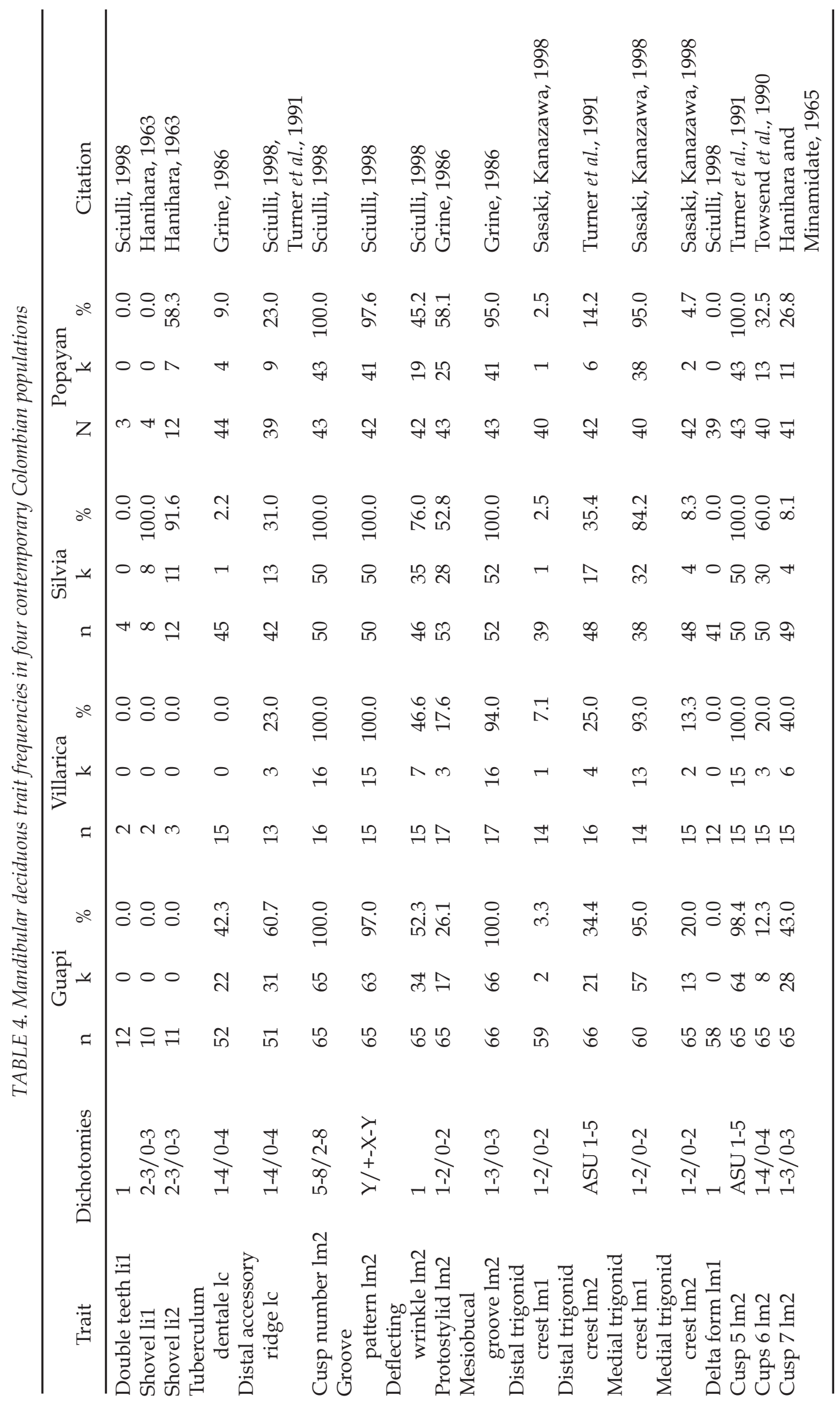




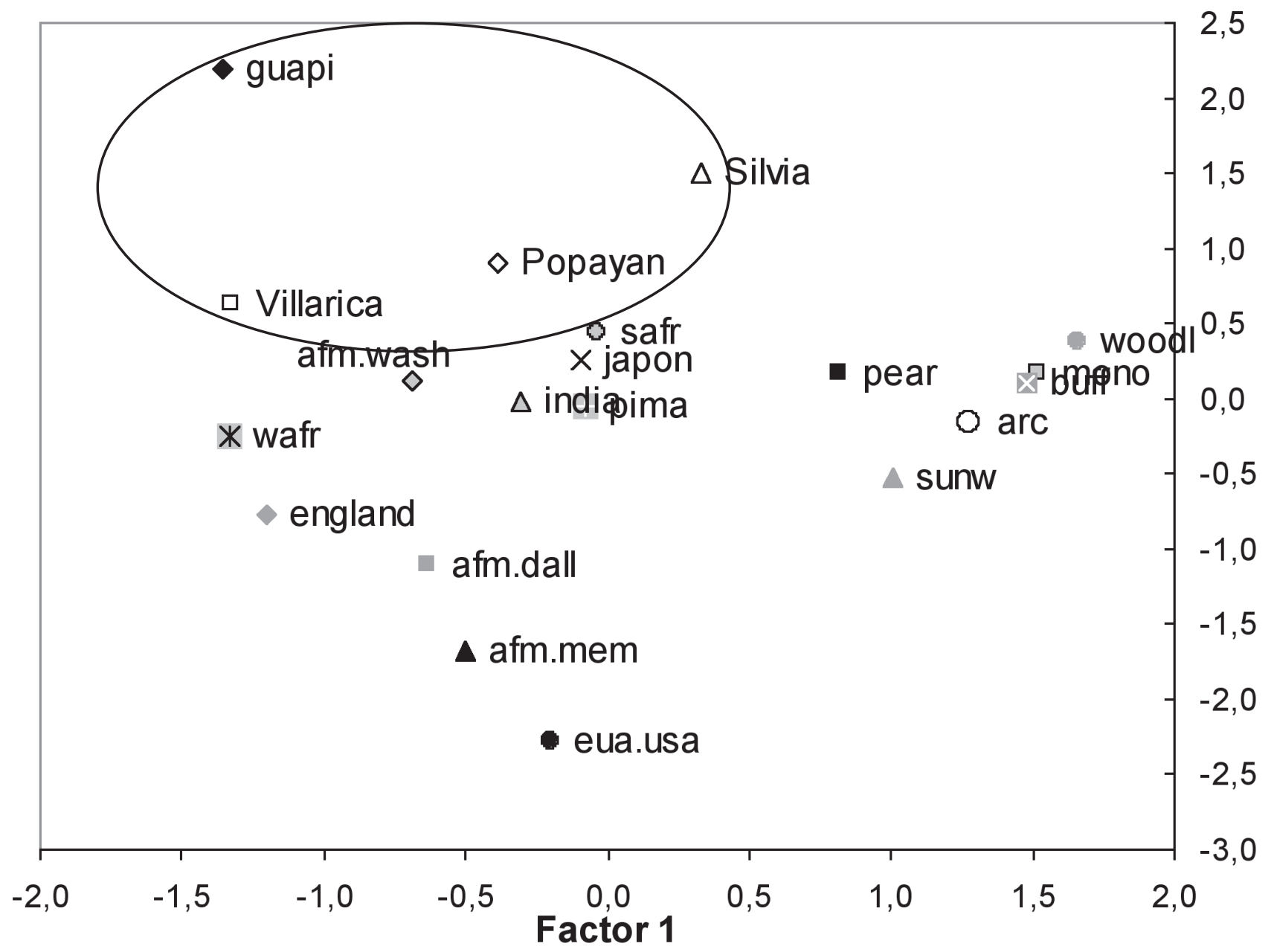

Fig. 2. Scatterplot of the first two components based on frequencies of traits in the deciduous dentition. A total of 20 samples are plotted. Axis 1 and 2 account for $50 \%$ of total variance ( $28.1 \%$ along X-axis and $21.5 \%$ along Y-axis). For codes and references see Tables 1 and 2. The ellipse includes the four Colombian samples studied.

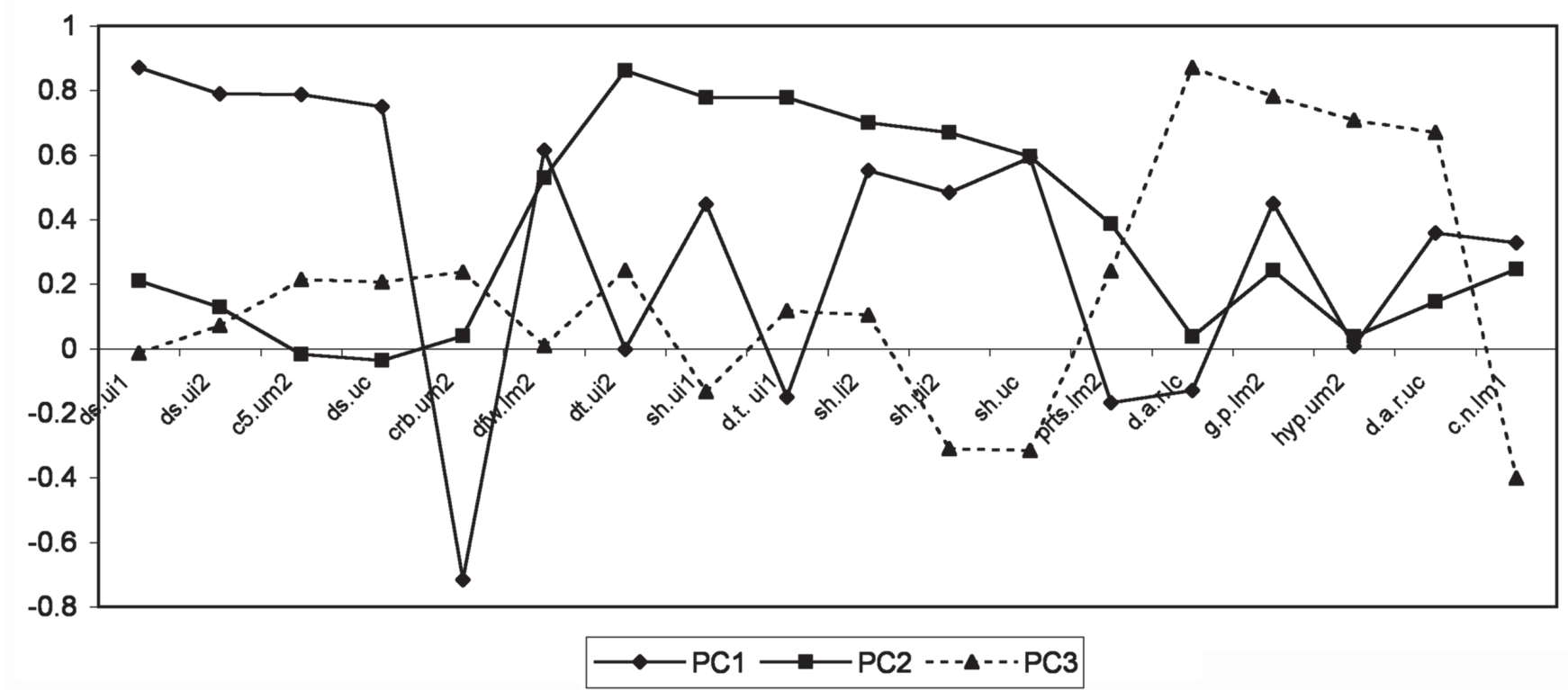

Fig. 3. Correlation coefficients (loadings) distribution in the three first principal components for 18 dental nonmetric traits between 20 populations of different ancestry with deciduous dentition. Accounts for $66.1 \%$ of total variance (28.1\% PC1, 21.5\% PC2, and 16.5\% PC3). 
exclusively on the use of C. A. B. Smith's mean measure of divergence (MMD) based on the distance concept or the degree of dissimilarity between samples (e.g., Irish, 1993; Scott and Turner, 1997).

The power of other analytic methods in the assessment of population affinities such as PCA has not been totally explored. The variables submitted to PCA (trait frequencies) are parametric (ratio scale), and frequencies of nonmetric traits can be used to produce numerically derived population relationships.

Recent studies employed PCA to assess population affinities using discontinuous dental traits with good results (Cucina et al., 2003; Coppa et al., 2001; Irish and Guatelli-Steinberg, 2003; Stringer, 2002; DelgadoBurbano, 2007). In fact, Irish and Guatelli-Steinberg (2003) and Coppa et al. (2007) compare PCA in great detail with other methods; in their case with statistics of distance as MMD, and they found very similar results, suggesting the reliability of PCA in the study of human population affinities using nonmetric traits.

The main benefit of PCA is that the reduced, conceptually more coherent, set of components is often easier to comprehend than the larger collection of potentially correlated variables (Irish and GuatelliSteinberg, 2003). However, the key reason for using PCA in the present study is that the correlations computed between original variables and components identify those dental traits that are most responsible for intersample variation. Only components with an eigenvalue higher than 1.0 were taken into account. Those correlation coefficients between a variable and the component that were higher than 0.6 were considered pertinent (Alfredo Coppa, personal communication, 2007).

The inter-group relationships based on the first two components-which contain much of the total variance-were plotted to discern relationships among samples via scatterplots produced by the graph function of SPSS 14.0.

\section{RESULTS}

The Colombian ethnic groups analyzed here did not exhibit significant sexual dimorphism in deciduous nonmetric traits. Two exceptions are for the Mestizo sample that exhibited two dental traits with significant male-female differences, namely Bushman canine uc $(\mathrm{P}$ $=0.037 ; 2 \mathrm{df})$ and Carabelli Tubercle um1 ( $\mathrm{P}=0.028 ; 2$ df). Irish (1993) suggested that dental traits exhibiting significant sexual dimorphism of less than $10 \%$ do not affect the population relationships. These traits only represent $5.4 \%$ (i.e., 2 of 37) and, accordingly, were not removed from the analysis. Subsequently, sexes were combined for the study of intergroup affinities.

Intergroup relationships are presented in Fig. 2. The PCA data for dental variants are presented in Table 5, which show the component loadings, eigenvalues, and percentages of variance explained by the dental traits. Fig. 3 depicts the significant correlation coefficients from among the 18 dental traits based on the PCA. PCA yielded three components that collectively account for $66.1 \%$ of the total variance. In each component, 16 dental traits were identified with significant positive $(>0.6)$ and negative $(>-0.6)$ correlation coefficients (loadings). In the first component ( $28 \%$ of total variance) six dental traits were identified, five with positive and one with negative loadings (Table 5). High frequency dental traits with a positive correlation coefficient characterize all populations with Asian-Sinodont ancestry. In fact, North and South Native American samples (both prehistoric and contemporary) and recent Asians (Japan) have high frequencies of these traits, which are ubiquitous in the "Mongoloid dental complex" (Hanihara, 1966). Some other groups with non-Asiatic ancestry also have high frequencies (African-Colombian, South Africans and Mestizo). On the other hand, one trait with a negative significant correlation coefficient in the first component was also identified. This has middle to high frequencies in Africans, African-Americans from North and South America, European-Americans and South Asians (India) analyzed here. Interestingly, all four Colombian samples have high frequencies of these traits. Their high frequency in African-Colombians and Mestizo groups is not surprising. However, Colombian Amerindians (Guambianos) have the second highest frequency after South Africans (based on the study by Grine, 1986). This observation possibly reflects high rates of admixture with populations of African or European ancestry.

In the second canonical axis ( $21.5 \%$ of total variance) six deciduous dental traits with positive significant correlation coefficients were identified. Once again, these traits characterize Asian-derived populations. Shovel ui1 is in high frequency in recent Japanese, prehistoric Native North Americans and contemporary Colombian Amerindians. Recent North-American Indians (Pima) have intermediate frequencies. AfricanAmericans from Dallas and Memphis (Lease, 2003) have high frequencies, suggesting admixture with Amerindians. This same pattern of biogeographic distribution is recognized for shovel shape in ui2, uc and li1. Europeans, European Americans and Mestizo samples share middle to high frequencies. Tuberculum dentale ui1 has high frequencies in African-Colombians from Guapi, European-Americans and Colombian Amerindians. Tuberculum dentale ui2 has similar frequencies in human groups with different ancestry; however, it showed a slight increase in Native Americans in general and in Colombian Mestizos.

Finally, the third canonical axis $(16.5 \%$ of total variance) identified four dental traits with significant positive loadings, however their population distributions are totally disparate. The first two dental traits (distal accessory ridge in upper and lower canines) have high frequencies in African-Colombians, West Africans, prehistoric North American Indians and recent Colombian Amerindians and Mestizo. Other 
TABLE 5. Component loadings, eigenvalues and variances for dental nonmetric traits in 20 populations of different ancestry with deciduous dentition ${ }^{1}$

\begin{tabular}{|c|c|c|c|}
\hline & & onents & \\
\hline Trait & PC1 & PC2 & PC3 \\
\hline Double shovel ui1 & 0.87 & 0.21 & -0.01 \\
\hline Double shovel ui2 & $\overline{0.79}$ & 0.13 & 0.07 \\
\hline Cusp 5 um2 & $\overline{0.79}$ & -0.02 & 0.21 \\
\hline Double shovel uc & $\underline{0.75}$ & -0.04 & 0.21 \\
\hline Carabelli um2 & $\underline{-0.72}$ & 0.04 & 0.24 \\
\hline Deflecting wrinkled $\operatorname{lm} 2$ & $\underline{0.62}$ & 0.53 & 0.01 \\
\hline Dental tubercle ui2 & 0.00 & $\underline{0.86}$ & 0.24 \\
\hline Shovel ui1 & 0.45 & $\underline{0.78}$ & -0.13 \\
\hline Dental tubercle ui1 & -0.15 & 0.78 & 0.12 \\
\hline Shovel li2 & 0.55 & $\underline{0.70}$ & 0.10 \\
\hline Shovel ui2 & 0.48 & $\underline{0.67}$ & -0.31 \\
\hline Shovel uc & 0.59 & $\underline{0.60}$ & -0.32 \\
\hline Protostylid lm2 & -0.17 & 0.39 & 0.24 \\
\hline Distal accesrory ridge lc & -0.13 & 0.04 & $\underline{0.87}$ \\
\hline Groove Pattern $\operatorname{lm} 2$ & 0.45 & 0.24 & $\underline{0.78}$ \\
\hline Hypocone um2 & 0.01 & 0.04 & $\underline{0.71}$ \\
\hline Distal accesory ridge uc & 0.36 & 0.14 & $\underline{0.67}$ \\
\hline Cusp number $\operatorname{lm} 1$ & 0.33 & 0.25 & -0.40 \\
\hline Eigenvalue & 5.05 & 3.88 & 2.98 \\
\hline Variance (\%) & 28.06 & 21.56 & 16.57 \\
\hline Cumulative Variance & 28.06 & 49.62 & 66.19 \\
\hline
\end{tabular}

${ }^{1}$ Highlighted entries denote relatively high positive and negative loadings within that particular component.

human groups studied here have low or mediumlow frequencies. The next two dental traits identified (hypocone um2 and groove pattern $\operatorname{lm} 2$ ) have very similar frequencies among human groups with different ethnic and biological ancestry. Hypocone um2 occurs in very high frequencies in all samples, ranging from $77 \%$ to $100 \%$. An exception is presented for EuropeanAmericans (Lease, 2003) who have very low frequency $(36 \%)$. This finding is possibly related to selection pressures - or simply sampling fluctuation. It is notable that this finding also occurs in New World African derived groups from Colombia (Delgado-Burbano, 2006). Groove pattern $\operatorname{lm} 2$ has nearly identical (90-100\%) frequencies across all dental samples, except European and African descendents from North America who have very low frequencies, which suggests intensive gene flow from ethnic groups of different ancestry.

Fig. 4 shows a comparison of the frequencies of those 16 dental traits most responsible for inter-group variation in the PC analysis (Table 5) among four Colombian samples analyzed. The fluctuations of dental trait frequencies reflect well the ancestry and microevolutionary dynamics between Colombian groups. Table 5 shows that dental traits with significant positive correlation coefficients in PC scores 1 and 2 characterize Native Americans and recent Asian populations (Sinodonts) (but see loading of Carabelli tubercle on PC1). Conversely, PC score 3 distinguishes groups with African and European ancestry. However, this pattern is very dynamic since some Asiandescendent samples have high frequencies of African and European dental traits and vice versa. In fact, Fig. 2 and 4 demonstrate that all Colombian groups have a relatively close biological relatedness to one another, as well as display a mixture of Asian and European-African dental morphological characters.

Within the four Colombian samples, Tables 3-5 and Fig. 4 show that African-Colombians have high frequencies of distal accessory ridge uc, hypocone um2, Carabelli tubercle um 2 and groove pattern $\operatorname{lm} 2$. On the other hand, Guambiano Amerindians have very high frequencies of shoveling and double shoveling in upper and lower central and lateral incisors and canines. Nonetheless this group has similar frequencies of the same dental traits that characterize African-Colombians (Fig. 4). Mestizos have traits very similar to AfricanAmericans and to Amerindians, confirming their highly admixed gene pool.

\section{DISCUSSION}

Ethnic groups of disparate ancestry are unevenly distributed around Colombia, and their patterns of 


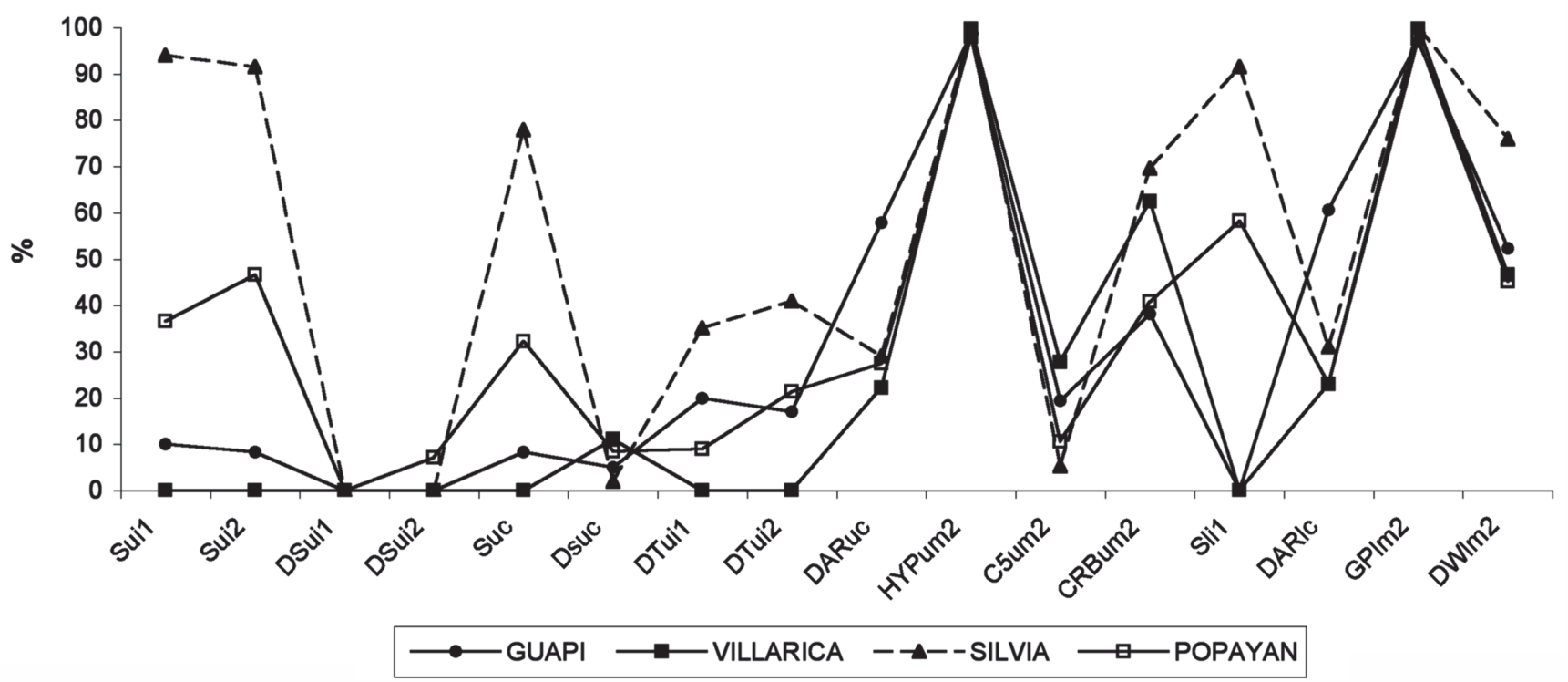

Fig. 4. Comparisons of the frequencies of 16 deciduous dental nonmetric traits more important for inter-sample variation according to PCA between four Colombian samples.

admixture vary considerably between and within regions. Some areas, such as Northwestern Colombia, were settled predominately by European males who admixed with Native American females. Other regions, such as the Pacific basin, have appreciable African ancestry. On the other hand, the Andean area is predominately Amerindian. Typically, neo-American societies were founded by populations with a high and medium maternal Amerindian contribution and a substantial European paternal contribution. In some American regions, in addition, variable percentages of paternal and/or maternal African contributions are also evident (Delgado-Burbano, 2007). For instance, one can find "Amerindian continental regions" (Peru, Mexico, Bolivia, Chile), "African continental regions" (Brazil and some areas of Colombia, Venezuela and Ecuador) and "European continental regions" (Argentina, Uruguay, Northwestern Colombia).

The evolutionary dynamics of contemporary Colombian populations have been analyzed almost exclusively by means of genetic markers (Ruiz-Linares et al., 1999; Mesa et al., 2000; Keyeux et al., 2002; Rodas et al., 2003; Carvajal-Carmora et al., 2000; Bedoya et al., 2006; Briceño et al., 2003; Melton et al., 2007; Bortolini et al., 2004; Salas et al., 2004, 2005). In consequence, little is known about the variation of morphological dental traits in these populations.

The population affinity analysis carried out here (Fig. 2) shows that Guambiano Amerindians have some affinities with prehistoric Native North Americans, but "close" affiliations with contemporary North American Indians and recent Northeast Asians were not evident. Recent molecular studies show close affinities between
Guambiano and other Native American populations from the Amazonas and Orinoco basin (Keyeux and Usaquen, 2005) - in contrast to a lack of affinity with North and Central American indigenous groups.

Interestingly, the present analysis also presents a more distant affinity with recent North American Amerindians, which agrees with the above-mentioned mtDNA analysis (Keyeux et al., 2002). Guambiano has predominately Sinodont dental traits; however, its high frequency of Carabelli tubercle possibly reflects European and/or African admixture. Previous genetic analysis based on blood groups corroborate this finding, suggesting that Guambiano-speaking people have $4.9 \%$ percent of African-descendent haplotypes as well as an unknown proportion of European admixture (Yunis et al., 2001). This indigenous group is characterized by conservative mating customs and deep cultural roots (Camacho, 1996). However, this dental study and genetic analyses show that their recent history underwent rather intensive gene flow from groups of different ancestry, specifically from Mestizos and/or African-descendents.

The sample of Colombian hybrids (Mestizos from Popayán) analyzed here has a high Amerindian and African component, while a European component is less evident. The history of Popayán dates back to the 16th century when Spanish conquerors founded this city. European male and Criollo (Spaniards born in American colonies) contributed substantially to the emergent population. Traditional Popayán inhabitants are culturally and phenotypically identified with their European ancestors. However, contrary to other Colombian regions such as Antioquia or Bogotá, Amerindian and African contributions are high. This 
trend reflects the general situation where high rates of gene flow among very different ethnic groups occur in urban centers in many Latin America countries (Sans, 2000). Rodas et al. (2003); Carvajal-Carmora et al. (2000) and Bedoya et al. (2006) previously showed that other Colombian Mestizo populations also have a high Amerindian component, but without a corresponding European or African contribution. The proportions of admixture for Northwestern Colombian region of Antioquia are as follows: 94\% European, 5\% African and 1\% Amerindian (Y-Chromosome data) and 2\% European, 8\% African and 90\% Amerindian (mtDNA data) (Carvajal-Carmora et al., 2000; Bedoya et al., 2006). Mestizos from Bogotá have $78 \%$ percent of Amerindian lineages $(\mathrm{A}=37.4$ and $\mathrm{B}=26.4 \%)$ and $22 \%$ of European lineages $(16.5 \%$ of $\mathrm{H}, \mathrm{T}, \mathrm{U} \mathrm{V}, \mathrm{W}$ and $2.2 \%$ of $\mathrm{J}$ or $\mathrm{K}$ or African haplotypes) (Rodas et al., 2003). The present dental analysis disagrees with these genetic studies since it suggests high African admixture and very low levels of gene flow from Europeans. This finding is interesting because Popayán inhabitants have a predominantly "European" cultural identity. However, this situation may be different in other Colombian regions.

Little is known about the microevolution and diversification of Africans and their descendents in Colombia. Only in the last decade have AfricanColombians been studied from a genetic point of view (Rodas et al., 2003; Keyeux, 1993; Keyeux et al., 2000; Bortolini et al., 2004; Salas et al., 2004, 2005). Traditionally, historical and anthropological studies have shown clear cultural, linguistic, and religious similarities among Afro-Colombians and western African Bantu-speakers (Schwengler, 1992; Colmenares, 1997; Del Castillo, 1982). Previous dental studies show that African-Colombians have close biological affinities with Sub-Saharan Africans (Delgado-Burbano, 2006, 2007). Specifically, samples from Western and Central Africa such Gabon, Congo Pygmy, Nigeria, Cameroon, Togo and Benin display dental morphological similarities with AfroColombians. This dental relatedness has been confirmed by mtDNA studies as well as historical records (Rodas et al., 2003; Keyeux et al., 2000; Salas et al., 2004, 2005; Bortolini et al., 2004; Del Castillo, 1982).

Additionally, these dental studies show unexpected population relationships between African-Colombians and eastern (Kenya and Tanzania) and southeastern Africans (South-Africa). In fact, these regions played a very important role in the importation of African slaves to Colombia - more than previously assumed. As Salas et al. (2005:857) pointed out: "there is also some indication of a Mozambican component in African-Americans of the Colombian Pacific Coast [i.e. Chocó] represented by the characteristic South eastern African mtDNA haplogroup founder $\mathrm{L} 0 \mathrm{a} 2$ and moreover the $\mathrm{L}^{\mathrm{e}} 1^{*}$ type present is typically Southeast African."

Interestingly, the landscape of genetic relatedness of African-Colombians and other South-AfricanAmericans are almost identical to the affinities displayed by dental nonmetric data. Dental information of African-Colombian samples analyzed here is consistent with previous dental analysis (Delgado-Burbano, 2006, 2007). Guapi and Villarica populations show close relationships with Western Africa. Although a close relationship with South Africa is not evident, the pattern of phenotypic affinities of African-Colombians suggests that Sub-Saharan Africa, specially western, eastern and southeastern Africa are important origin regions.

Fig. 2 shows that African-American Colombian samples have clear affinities with African-Americans from Washington but not with African-Americans from Memphis and Dallas (comparative data from Lease, 2003). This finding could suggest both different ethnic origins of African-American populations in the Americas and/or distinct microevolutionary histories. Previous dental analyses (Lease, 2003; DelgadoBurbano, 2007) show that North-African-Americans have close affinities with European-Americans due to intensive gene flow that modified their gene pools and therefore their biological associations with other Africandescendent populations and their African ancestors. Rodas et al. (2003) based mtDNA haplogroup analysis shows asymmetrical patterns of admixture in AfricanColombians that disagree with the present study. Several samples from the Pacific basin have medium and high admixture with Native Americans. Specifically a significant proportion of Amerindian lineages A (mean frequency: $8.2 \%$ ) and B (mean frequency: $10.6 \%$ ) were detected. Although frequencies of incisor shoveling and deflecting wrinkle in Guapi and Villarica possibly indicate the presence of a Native American component in their gene pool, population affinities shown in Fig. 2 and dental frequencies presented in Fig. 4 imply a low rate of admixture between Colombian Native Americans and African-descendents, in agreement with more recent mtDNA analysis (Salas et al., 2004, 2005).

In conclusion, Colombian samples analyzed here present a complex history, where gene flow probably was the main factor configuring the contemporary gene pools. Although some samples show disparate ancestries in their dental morphology (i.e., Mestizo), other groups (African-Colombians and Amerindians) appear to share close relationships with their sister and parental populations. Patterns of phenotypic diversity of these Colombian groups probably parallel those that have occurred in other Latin-American populations in similar historical contexts.

\section{ACKNOWLEDGMENTS}

I thank the Colombian communities that participated in this study; without their help it would not have been possible. This study was partially supported by a grant of the Colombian Institute for the Development of 
Science and Technology COLCIENCIAS (1103-04-11985) and Antropos and Antropacifico research groups of the Department of Anthropology, University of Cauca, Colombia. Thanks to Alexandra Delgado for grammatical editing of the manuscript. Thanks to Dr. Javier Rosique (Department of Anthropology, Antioquia University, Colombia) for his useful comments and assistance.

\section{LITERATURE CITED}

Bedoya G, Montoya P, García J, Soto I, Burgeois S, Carvajal L, Labuda D, Alvarez V, Ospina J, Hedrick PW, Ruiz-Linarez A. 2006. Admixture dynamics in Hispanics: a shift in the nuclear genetic ancestry of a South American population isolate. Proc Natl Acad Sc USA 103:7234-7239.

Bortolini MC, Silva-Jr WA, Zago MA, Elion J, Krishnamoorth R, Gonçalves VP, Pena SD. 2004. The phylogeography of mitochondrial DNA haplogroup L3g in Africa and the Atlantic slave trade. Am J Hum Genet 74:523-524.

Briceño I, Gomez, A, Lozano PA. 2003. Mitochondrial variation in Colombia: study of matrilineal lineages among Amerindian tribes. XIX Proceedings of the International Congress of Genetics, Melbourne.

Carvajal-Carmora LG, Soto ID, Pineda N, OrtizBarrientos D, Duque C, Ospina-Duque J, McCarthy M, Montoya P, Álvarez VM, Bedoya G, Ruiz-Linares A .2000. Strong Amerind/white sex bias and possible Sephardic contribution among the founders of a population in the Northwestern Colombia. Am J Hum Genet 67:1287-1295.

Colmenares G. 1997. Historia Económica y Social de Colombia II. Popayán una Sociedad Esclavista. 16801800. Bogotá. La Carreta Inéditos Ltda.

Coppa A, Cucina A, Lucci M, Vargiug R, Maccinelli D. 2007. Origins and spread of agriculture in Italy: a nonmetric dental analysis. Am J Phys Anthropol 133:918-930.

Coppa A, Di Cinto F, Vargiu R, Maccinelli D, Lucci M. 2001. Morphological dental traits to reconstruct phenetic relationships between Late PleistoceneAncient Holocene human groups from Eurasia and North Africa. Am J Phys Anthropol (Suppl) 32:54

Cucina A, Luna F, Vargiu R, Coppa A. 2003. Las poblaciones caribeñas desde el tercer milenio AC a la conquista española: las filiaciones biológicas desde la perspectiva antropológica dental. Estudios de Antropología Biológica XI:913-927.

Del Castillo NM. 1982. Esclavos Negros en Cartagena y sus Aportes Léxicos. Bogotá. Instituto Caro y Cuervo.

Delgado-Burbano ME. 2006. Historia poblacional, orígenes Africanos y microevolución de los actuales Afro-Colombianos inferidos desde caracteres epigenéticos en la dentición decidua y permanente. Rev Arg Antropol Biol 8:85-109.
Delgado-Burbano ME. 2007. Population affinities of African Colombians to Sub-Saharan Africans based on dental morphology. Homo 58:329-356.

Edgar H, Lease L. 2007. Correlations between deciduous and permanent mandibular molars in a European-American sample. Am J Phys Anthropol 133:726-734.

Ethnologue 2001. Language of the World. 14th ed. Electronic version. Http://ethnologue.com/snow_ country.asp?name $=$ Colombia.

Grine FE. 1984. The deciduous dentition of the Kalahari San, the South African Negro and the South African Plio-Pleistocene hominids. Ph.D. dissertation. Johannesburg. University of Witwatersrand. South Africa.

Grine FE. 1986. Anthropological aspects of the deciduous teeth of South African blacks. In: Singer RJ, Lundy, editors. Variation, culture and evolution in African populations. Johannesburg. Witwatersrand University Press, p 47-83.

Grine FE. 1990. Deciduous dental features of Kalahari San: comparisons of non-metrical traits. In: Sperber $\mathrm{GH}$, editor. From the apes to angels. New York. Wiley-Liss, p 153-169.

Hanihara K. 1956a. Studies on the deciduous dentition of the Japanese and the Japanese-American hybrids. III. Deciduous lower molars. J Anth Soc Nippon 65:95-115.

Hanihara K. 1956b. Studies on the deciduous dentition of the Japanese and the Japanese-American hybrids. IV. Deciduous upper molars. J Anth Soc Nippon 65:67-87.

Hanihara K. 1961. Criteria for the classification of crown characteristics of the human deciduous dentition. J Anth Soc Nippon 69:27-45.

Hanihara K. 1963. Crown characters of the dentition of the Japanese-American hybrids. In: Brothwell DR, editor. Dental anthropology. London: Pergamon Press, p 104-124.

Hanihara K. 1965. Some crown characters of the deciduous incisors and canines in Japanese-American hybrids. J Anth Soc Nippon 72:135-145.

Hanihara K. 1966. Mongoloid dental complex in the deciduous dentition. J Anth Soc Nippon 74:61-71.

Hanihara K, Minamidate T. 1965. Tuberculum accesorium mediale internum in the human deciduous lower second molars. J Anth Soc Nippon 73:9-18.

Irish JD. 1993. Biological affinities of Late Pleistocene through modern African aboriginal populations: the dental evidence. Ph.D. Dissertation, Arizona State University, Tempe Arizona.

Irish J, Guatelli-Steinberg D. 2003. Ancient teeth and modern human origins: an expanded comparison of African Plio-Pleistocene and recent world dental samples. J Hum Evol 45:113-144.

Jaramillo-Correa JP, Keyeux G, Ruiz-Garcia M, Rodas C, Bernal. 2001. Population study of the genes 
APOE, APOB ( $\left.3^{\prime} \mathrm{VNTR}\right)$ and $\mathrm{ACE}$ in some Black and Amerindian communities from Colombia. Hum Hered 52:14-33.

Jørgensen K. 1956. The deciduous dentition: a descriptive and comparative anatomical study. Acta Odont Scand 14:1-202.

Keyeux G, Usaquén W. 2005. Rutas migratorias hacia Sur América y el poblamiento de las cuencas de los ríos Amazonas y Orinoco deducidas a partir de estudios genéticos moleculares. In Pueblos y Paisajes Antiguos en la Selva Tropical Amazónica, p 1-30.

Keyeux G, Rodas C, Gálvez N, Carter D. 2002. Possible migration routes into South America deduced from mtDNA studies in Colombian Amerindian populations. Hum Biol 74:211-233.

Keyeux G, Rodas C, Bernal JE. 2000. Haplotipos fundadores del DNA mitocondrial en poblaciones colombianas: aporte a los estudios en América. In: Bernal J, editor. Geografía Humana de Colombia. Instituto Colombiano de Cultura Hispánica, p 453466.

Kitagawa Y. 2000. Nonmetric morphological characters of deciduous teeth in Japan: diachronic evidence of past 4000 years. Int J Osteoarch 10:242-253.

Lease L. 2003. Ancestral determination of AfricanAmericans and European-Americans deciduous dentition using metric and non-metric analysis. Ph.D. dissertation. Ohio State University, Columbus, Ohio.

Lease L, Sciulli P. 2005. Brief communication: discrimination between European-American and African-American children based on deciduous metrics and morphology. Am J Phys Anthropol 126:56-60.

Lukacs J, Hemphill B. 1991. The dental anthropology of prehistoric Baluchistan: a morphometric approach to the peopling of South Asia. In: Kelley M, Larsen CS, editors. Advances in dental anthropology. New York: Willey-Liss, p 77-119.

Lukacs, JR, Walimbe SR. 1984. Deciduous dental morphology and the biological affinities of a Chalcolithic skeletal series from Western India. Am J Phys Anthropol 65:23-30.

Melton PE, Briceño I, Gomez A, Crawford M, Benal J. 2007. Biological relationships between Central and South American Chibcha speaking populations: evidence from mtDNA. Am J Phys Anthropol 133:753-770.

Mesa N, Mondragón M, Soto I, Parra MV, Duque C, Ortíz-Barrientos D, García LF, Vélez ID, Bravo ML, Múnera GJ, Bedoya G, Bortolini MC, Ruiz-Linares A. 2000. Autosomal mtDNA, and Y-chromosome diversity in Amerinds: pre- and post-Columbian patterns of gene flow in South America. Am J Hum Genet 67:1277-1286.

Moskona D, Vainder M, Hershkovitz I, Kobyliansky
E. 1998. Dentition peculiarities in human isolates South Sinai Beduin tribes. In: Mayhall J, Heikkinen T, editors. Dental morphology 1998: 11th International symposium on dental morphology. Oulu: Finland, $\mathrm{p}$ 74-84.

Nichol C. 1989. Complex segregation analysis of dental morphological variants. Am J Phys Anthropol 78:3759.

Pachón X. 1996. Los Wampi o la gente de Guambía. In Pachón X, Oliveros E, Wiesner L, editors. Geografía Humana de Colombia. Región Andina. Instituto Colombiano de Cultura Hispánica. Colombia, p 1185.

Rocha L, Rivas H, Moreno F. 2007. Frecuencia y variabilidad de la morfología dental en niños AfroColombianos de una institución educativa en Puerto Tejada, Cauca, Colombia. Colombia Médica 38:210221.

Rodas C, Gelvez N, Keyeux G. 2003. Mitochondrial DNA studies show asymmetrical Amerindian admixture in Afro-Colombian and Mestizo populations. Hum Biol 75:13-30.

Ruiz-Linares A, Ortíz-Barrientos D, Figueroa M, Mesa N, Múneras JG, Bedoya G, Vélez ID, García FL, PérezLezaun A, Bertranpetit J, Feldman MV, Goldstein DV. 1999. Microsatellites provide evidence for $Y$ chromosome diversity among the founders of the New World. Proc Natl Acad Sci USA 96:6312-6317.

Salas A, Richards M, Lareu MV, Scozzari R, Coppa A, Torroni A, Macaulay V, Carracedo A. 2004. The African diaspora: mitochondrial DNA and the Atlantic slave trade. Am J Hum Genet 74:454-465.

Salas A, Richards M, Lareu MV, Sobrino B, Silva S, Matamoros M, Macaulay V, Carracedo A. 2005. Shipwrecks and founder effects: divergent demographic histories reflected in Caribbean mtDNA. Am J Phys Anthropol 128:855-860.

Schwengler A. 1992. Hacia una arqueología afrocolombiana: Restos de tradiciones religiosas Bantúes en una comunidad negro-colombiana. América Negra 4:35-82.

Sans M. 2000. Admixture studies in Latin America: from 20th to 21st century. Hum Biol 72:155-177.

Sasaki K, Kanazawa E. 1998. Morphological traits on dentino-enamel juction of lower deciduous molar series. In: Mayhall J, Heikkinen T, editors. Dental morphology 1998: 11th international symposium on dental morphology. Oulu, Finland: University of Oulu, p 167-178.

Sciulli PW. 1977. A descriptive and comparative study of deciduous dentition of prehistoric Ohio Valley Amerindians. Am J Phys Anthropol 47:71-80.

Sciulli, PW. 1990. Deciduous dentition of a Late Archaic population of Ohio. Hum Biol 62:221-245.

Sciulli PW. 1998. Evolution of the dentition prehistoric Ohio Valley Native Americans: II. morphology of the 
deciduous dentition. Am J Phys Anthropol 106:189205.

Scott GR. 1980. Population variation of Carabelli's trait. Hum Biol 52:63-78.

Scott RG, Turner CG II. 1997. The anthropology of modern human teeth: dental morphology and its variation in recent human populations. Cambridge: Cambridge University Press.

Smith P. 1978. Evolutionary changes in the deciduous dentition of Near Eastern populations. J Hum Evol 7:401-408.

Smith PE, Koyoumdisky-Kaye, Kalderon W, Stern D. 1987. Directionality of dental trait frequency between human second deciduous and first permanent molars. Arch Oral Biol 32:5-9.

Tocheri M. 2002. The effect of sexual dimorphism, asymmetry and inter-trait association on the distribution of thirteen deciduous dental nonmetric traits in a sample of Pima Indians. Dental Anthropology 15:1-9.

Townsend GC, Martin N. 1992. Fitting genetic models to Carabelli trait data in South Australian twins. J Dent
Res 71:403-409.

Townsend GC, Brown T. 1981. The Carabelli trait in Australian aboriginal dentition. Arch Oral Biol 26:809-814.

Townsend GC, Yamada H, Smith P. 1986. The metaconule in Australian aboriginals: an accessory tubercle on maxillary molar teeth. Hum Biol 58:851-862.

Townsend GC, Yamada H, Smith P. 1990. Expression of the entoconulid (sixth cusp) on mandibular molar teeth of an Australian aboriginal population. Am J Phys Anthropol 82:267-274.

Turner CG, Nichol C, Scott R. 1991 Scoring procedures for key morphological traits of the permanent dentition: the Arizona State University Dental Anthropology System. In: Kelley M, Larsen CS, editors. Advances in dental anthropology. New York: Willey-Liss, p 1331.

Ullinger, J. 2003. A comparison of morphological traits in deciduous and permanent dentition. Am J Phys Anthropol (Supp) 36:212.

Yunis JJ, Yunis EJ, Yunis E. 2001. Genetic relationship of the Guambino, Paez, and Ingano Amerindians of Southwest Colombia using major histocompatibility complex class II haplotypes and blood groups. Hum Immunol 62:970-978. 